\title{
Gendered Student Political Participation And The Influences Of Voluntary Organizations
}

\author{
Dzuriyatun Toyibah \\ FISIP UIN Syarif Hidayatullah Jakarta
}

\begin{abstract}
Student political participation is gendered. It can be ascertained from the data presented in this paper that female students participate less actively than male students all seven forms of political participation; demonstration, signing petitions, blocking traffic, occupying buildings, boycotting, damaging public facilities, and striking. This parallels the level of participation of female students in voluntary organizations, as can be deduced from the survey I conducted, detailing the level of participation of male and female students in UIN Jakarta in 2012. The sample consists of 388 students, where $216(55.7 \%)$ are female students, and $172(44,3 \%)$ are male. My research follows that of Seda (2002), Nurland (2002), and Soetjipto (2005) [1]. Furthermore, it supports the findings of previous researchers, who argue that voluntary organization is a significant indicator of one's level of political participation $[2,3]$.
\end{abstract}

Keywords : Gender, Student, Political Participation

\section{INTRODUCTION}

Women in Indonesian politics continue to be marginalized [1]. It has been argued that most women are not yet psychologically ready to actively participate in politics due to the cultural values that have been ingrained in them since childhood. They lack confidence and still have a negative perception of politics [1]. Nationally, the gendered nature of political participation is evident from women's representation in Parliament. There were only $18.4 \%$ (101) women in 20092014, and $17.32 \%$ (97) women in 2014-2019.

The lack of women in politics has been investigated before. For example, Rustanto concluded that the social precondition for the presence of women in politics had not been achieved; women still have limitations on their freedom to articulate their aspirations. In addition, support from the organization and constituent does not yet exist. Therefore, women are only considered the targets and objects of government programs [4]. Similarly, Fatmariza argues that despite the social capital that belonged to women in Minangkabau, as they held the main position in their society, they haddifficulty playing significant roles during the period of decentralization [5].

This article discusses gendered student political participation to compare male and female student political participation and its correlation with participation in voluntary organizations. It has been argued that students were significantly involved in every period of Indonesian's political transitions, such as the history of independence of Indonesia, and the fall of the Sukarno regime from the old order to the new order. Similarly, student movements played a significant role during the period of transition from the new order to the reformasi period in 1998, but those have not paid attention to the gender aspect $[6,7,8]$. The institutional theory argues that social institutions, such as religious institutions and educational institutions, are significantly correlated to political participation. This view of political participation differs from others that argue that social and economic status is the primary determinant. Religious organizations, which are classified as voluntary associations, can facilitate the development of a social contract, which can build a network. These networks facilitate communication between government officials and the people $[2,3,9,10]$.

The aim of this paper is to fill the academic gap regarding the role of gender in determining student political participation and discussion. Therefore, this paper will answer at least two questions: do female studentsparticipate in politics as intensively as male students, and do gender and participation in voluntary organizations affect student political participation. A hypothesis has been identified:

Ho: Female students participate in politics and voluntary organizations as intensively as male students.

Ha: Female students do not participate in politics and voluntary organizations as intensive as male students

\section{DEFINING AND MEASURING POLITICAL PARTICIPATION AND VOLUNTARY ORGANIZATION}

In a democratic society, all citizens have the right to actively participate in politics. Democracy requires that people participate in politics because political participation is a requirement for democracy. The basic definition of political participation is; a private citizen performing activities that influence the government's public policies [18]. Burns et al. define political participation as various activities that influence the government's policies directly or indirectly, by influencing the election of public officials.In short, political participation is the activities of a citizen that influence local or national public policies [21, 2, 3].

Several measures of political participation have been used in previous research.Previous studies have examined three forms of political participation: voting, campaigning, and community activities [11, 12].Persson divided 13 types of political participation into three classification: first, traditional political participation (membership in a political party, contacting political representatives, writing letters to support 
political candidates); second, in parliament participation (boycotting, wearing political attributes, signing petitions, demonstrations); and illegal political participation (blocking traffic, occupying buildings, spray painting) [13]. Taylor and Clerkin classified political participation into four main activities: campaigning, contributing for and donating to politics, participation in the communal activity, and political discourse [14].On the other hand, Swank emphasized the importance of social change as the goal for political participation. Political participation includes activities such as signing petitions, writing letters about public interest, showing political identity and symbols, contributing towards and donating to politics, voting, demonstrating, civil obedience, and protesting [15].

Participation in networks of civic engagements is important in a democracy because it helps people obtain information about public policy and it can support social action to influence the government's policies. The voluntary organization can provide not only resources for political participation [16] but can also be mobilized by political leaders [2].

Similarly, Olsen argued that the involvement in the voluntary association can activate individuals politically for several reasons: first, it expands people's interest in public issues and ensures that they will be considered important. Second, those who participate actively in voluntary organizations will make contact with a greater number of people and thus increase their connectivity to public issues and political activities. Third, participation creates leadership skills, and social interaction provides other important resources for effective political action [2].

On the other hand, Stout considers the voluntary organization as a measure of social capital and has found that social, economic status is positively correlated with a voluntary organization. Participation in voluntary organizations is a latent variable and is measured in three ways: the number of memberships, the positions, whether the membership is in voluntary organizations that support social reform. The number of memberships is an interval variable scored from 1-14 (based on number and type of voluntary organization), and each membership and type of organization is counted 1. Play a role in organization's leadership membership in voluntary organization to support social reform are dummy variable (Yes or No question) [16].

\section{GENDER AND STUDENT POLITICAL PARTICIPATION}

Concerning student political participation, it has argued that students tend to play an oppositional role [17]. It strengthens Huntington' arguments that students in developing countries tend to oppose all regimes [8], and similarly, Altbach found that despite the fact that students are a minority compared to other groups, they have played a significant role in politics. Student's characteristics, according to Altbach are quite independent of conservative values, as they have good access to open and new ideas, and are typically located in big cities. In general, students are expected to oppose and criticize bad political practices and return them to their appropriate function [19]. This role has been thrust upon students, and they have been the moral keepers of politics. However, all assumptions about the role of students only apply to male students.

Studies of student political participation have been intensely conducted in many countries outside Indonesia. Swank examined predictors of political participation for students of the social work faculty from demographic factors, such as social, economic status, gender, and students'approval of mobilized structure and collective action frame. [15] Taylor and Clerkin tested demographic factors and public service motivation (PSM)[14]. Simmons and Lily examined the influence of the learning process on student political participation [20]. Mc.Farland and Thomas tested the influence of volunteer organizations in school on adult participation [11]. Evan compares youth political participation between college and non-collegeparticipants [9].

Previous researchers have found various results regarding the influence of gender on student political participation. Swank found that gender was negatively influenced by protest activities; especially it has negatively influenced female students from conservative groups. On the other hand, Taylor and Clerkin did not give a comprehensive explanation of the role of gender but realized that their regressions showed a negative impact of gender on political participation [15, 20]. Persson, found that gender was only a significant factor for new students, however, testing this factor a year later for the same participantsyielded results that indicated gender was insignificant [13]. Simmons and Lily came to a similar conclusion to that of Swank's; that gender was a significant factor in determining the extent of political participation [20].

\section{GENDERED STUDENT POLITICAL PARTICIPATION AT UIN SYARIFHIDAYATULLAH JAKARTA}

My study will examine a survey of 388 active students at UIN Jakarta. The percentage of male and female participation reflects the percentage of men and women in the general population (44.3\% and 55.7 for male and female students respectively).Questions include students' political participation: have they participated in seven political participation activities in the last three years (demonstration, signing the petition, blocking traffic, occupying building, boycott, damaging public facilities, striking).This paper focuses on gendered political participation and participation in voluntary organizations. In general, the survey has found that male students are still very dominant in various activities classified as political participation and are still more active in voluntary organizations.

\section{DEMONSTRATION AND OTHER OPPOSITION ACTIVITIES}

Compared to other opposition activities, the demonstration is the most popular. This form of participation 
is favorably viewed and can motivate some to protest inappropriate policies later.35\% of the surveyed students claimed that they participated in demonstrations in the last three years. This percentage is five times greater than the percentage of students polled in previous surveys [2]. Male students are very dominant compared to the female student.

Table.1 Student Political Participation

\begin{tabular}{|c|c|c|c|c|c|c|c|}
\hline $\begin{array}{c}\text { N } \\
\text { o }\end{array}$ & \multicolumn{2}{|c|}{ Male } & \multicolumn{2}{c|}{ Female } & \multicolumn{2}{c|}{ Total } \\
\hline 1 & $\begin{array}{c}\text { Demonstrati } \\
\text { on }\end{array}$ & 94 & $25 \%$ & 39 & $10 \%$ & $\begin{array}{c}13 \\
3\end{array}$ & $35 \%$ \\
\hline 2 & $\begin{array}{c}\text { Signing } \\
\text { Petition }\end{array}$ & 63 & $\begin{array}{c}16.7 \\
\%\end{array}$ & 40 & $\begin{array}{c}10.6 \\
\%\end{array}$ & $\begin{array}{c}10 \\
3\end{array}$ & $\begin{array}{c}27.3 \\
\%\end{array}$ \\
\hline 3 & $\begin{array}{c}\text { Blocking } \\
\text { Traffic }\end{array}$ & 25 & $7 \%$ & 6 & $2 \%$ & 31 & $9 \%$ \\
\hline 4 & $\begin{array}{c}\text { Occupying } \\
\text { Building }\end{array}$ & 23 & $6 \%$ & 7 & $2 \%$ & 30 & $8 \%$ \\
\hline 5 & Boycott & 16 & $4 \%$ & 4 & $1 \%$ & 20 & $5 \%$ \\
\hline 6 & $\begin{array}{c}\text { Damaging } \\
\text { public } \\
\text { facilities }\end{array}$ & 6 & $2 \%$ & 6 & $2 \%$ & 12 & $4 \%$ \\
\hline 7 & Striking & 9 & $2 \%$ & 4 & $1 \%$ & 13 & $3 \%$ \\
\hline
\end{tabular}

Signing petitions are the second most popular opposition activity after the demonstration. $27.3 \%$ of students surveyed admitted that they had participated by signing petitions in the last three years. The percentage gap between male and female students that sign petitions is not as wide as the gap between male and female students that participate in demonstrations. The percentage of students that sign petitions has increased compared to previous survey [2], $10 \%$ of the students have participated by signing petitions.

Radical and illegal opposition activities are not very common among students. However, the percentage of studentsthat participate in illegal and radical activities is still higher than that found in previous research [2]. The percentages of students that participate in politics by blocking traffic, occupying buildings, and boycotting are 9\%, 8\%, and $5 \%$ respectively, compared to the $2 \%$ for occupying buildings and $1 \%$ for blocking traffic in previous research. The percentage of the last type of political participation, damaging public facilities, is the lowest, $4 \%$ and $3 \%$ respectively.

\section{VOLUNTARY ORGANIZATION'S PARTICIPATION}

Previous studies have shown that involvement in voluntary associations is important for democracy. Data collected in this study includes the percentage of student involvement in selected voluntary organizations, such as religious organizations, community organizations (KarangTaruna/youth organizations, and sports organizations, Arisan/rotating money). The participation in religious organizationsrefers only to leadership experience in such organizations. The question is: do you have experience being on board in a religious organization? $9.3 \%$ of male students and $9.8 \%$ of female students have had experiences in religious leadership. It is interesting that more female students have had experience in this area.

Table.2Voluntary organization/activities

\begin{tabular}{|c|c|c|c|c|c|}
\hline \multirow[b]{2}{*}{$\begin{array}{c}\mathrm{N} \\
\mathrm{O}\end{array}$} & \multirow[b]{2}{*}{$\begin{array}{c}\text { Voluntary } \\
\text { organization/activities }\end{array}$} & \multicolumn{2}{|c|}{ Male } & \multicolumn{2}{|c|}{ Female } \\
\hline & & Yes & $\begin{array}{l}\mathrm{No} / \mathrm{N} \\
\mathrm{o} \\
\text { Answ } \\
\text { er }\end{array}$ & Yes & $\begin{array}{l}\text { No/No } \\
\text { Answ } \\
\text { er }\end{array}$ \\
\hline 1 & $\begin{array}{c}\text { Leadership experience } \\
\text { in religious } \\
\text { organization } \\
\end{array}$ & $9.3 \%$ & $\begin{array}{c}90.7 \\
\% \\
\end{array}$ & $\begin{array}{c}9.8 \\
\%\end{array}$ & $90.2 \%$ \\
\hline 2 & $\begin{array}{c}\text { Youth } \\
\text { Organization/Karang } \\
\text { Taruna }\end{array}$ & $\begin{array}{c}42.3 \\
\%\end{array}$ & $\begin{array}{c}57.7 \\
\%\end{array}$ & $\begin{array}{c}28.7 \\
\%\end{array}$ & $71.3 \%$ \\
\hline 3 & Sport organization & $\begin{array}{c}62.5 \\
\%\end{array}$ & $\begin{array}{c}37.5 \\
\%\end{array}$ & $\begin{array}{c}31.6 \\
\%\end{array}$ & $68.4 \%$ \\
\hline 4 & $\begin{array}{l}\text { Arisan (rotating } \\
\text { money) }\end{array}$ & $\begin{array}{c}14.30 \\
\%\end{array}$ & $\begin{array}{c}85.7 \\
\%\end{array}$ & $\begin{array}{c}34.4 \\
\%\end{array}$ & $65.6 \%$ \\
\hline 5 & Student organizations & $\begin{array}{c}82.1 \\
\%\end{array}$ & $\begin{array}{c}17.9 \\
\%\end{array}$ & $\begin{array}{c}70.3 \\
\%\end{array}$ & $29.7 \%$ \\
\hline
\end{tabular}

Female students are more active than male student only in arisan (rotating money), with $34.4 \%$ of them participating compared to only $14.3 \%$ participation by male students.Male students are more active in other activities (youth organization/karangtaruna and sports organization). Student organizations are the most appropriate voluntary activity for measuring student engagement in voluntary organizations. Participants can choose more than one answer when asked the kinds of organizations they have participated in. Thus the percentage is not related to the total participants but rather is based on gender. Male student participation is more dominant as only $17.9 \%$ have not participated actively in student organizations, on the other hand, $29.7 \%$ of female students have not actively participated in student organizations.

\section{GENDER, VOLUNTARY ASSOCIATION AND POLITICALPARTICIPATION}

The impact of membership in voluntary organizations and gender on political participation in Indonesia has been studied previously [2,3]. Based on those studies it can be argued that the gender gap in political participation in Indonesia is still prevalent, and gender is a significant factor that determines political participation. Accordingly, it can be assumed that women participate less in voluntary organizations. It is not surprising that voluntary organizations have impacted inequality in political participation because 
non-political institutions, such as family, have impacted inequality in political participation too [22].

This study strengthens the previous studies arguing that both voluntary association and political participation are gendered and both are significant factors for determining political participation (see table 3 ). The difference between the level of male and female student participation in student organizations and youth organizations is very significant. Both kinds of organizations introduce social and political issues and leadership opportunities. The low level of female participation in both organizations correlates to the low level of female political participation. Similarly, the high level of male participation in both organizations correlated to the high level of male political participation.

Table 3 Individual Test

\begin{tabular}{|c|c|c|c|c|}
\hline No & hyphothesis & t count & t table & conclusion \\
\hline 1 & $\rho$ Age $\neq 0$ & 0,24 & 1,97 & $\mathrm{H}_{0}$ accepted \\
\hline 2 & $\rho$ Gender $\neq 0$ & 4,94 & 1,97 & $\mathrm{H}_{0}$ rejected \\
\hline 3 & $\rho$ Semester $\neq 0$ & 0,81 & 1,97 & $\mathrm{H}_{0}$ accepted \\
\hline 4 & $\begin{array}{l}\rho \text { Community } \\
\text { Organizatiom } \\
\quad \neq 0\end{array}$ & 0,96 & 1,97 & $\mathrm{H}_{0}$ accepted \\
\hline 5 & $\begin{array}{c}\text { pStudent } \\
\text { organization } \neq \\
0\end{array}$ & 6,75 & 1,97 & $\mathrm{H}_{0}$ rejected \\
\hline 6 & $\begin{array}{c}\rho \text { Non- } \\
\text { religious } \\
\text { organization } \neq \\
0 \\
\end{array}$ & 0,80 & 1,97 & $\mathrm{H}_{0}$ accepted \\
\hline 7 & $\begin{array}{c}\rho \text { Family } \\
\text { socialization } \neq \\
0 \\
\end{array}$ & 0,17 & 1,97 & $\mathrm{H}_{0}$ accepted \\
\hline 8 & pinternet $\neq 0$ & 7,58 & 1,97 & $\mathrm{H}_{0}$ rejected \\
\hline 9 & $\rho S S E \neq 0$ & $-1,78$ & 1,97 & $\mathrm{H}_{0}$ accepted \\
\hline
\end{tabular}

Individual testing for nine independent variables, with political participation as the dependent variable, shows that gender and student organization are significant factors. In this research, student organizations represent voluntary organizations that provide positive environments for political participation.

\section{REFERENCE}

[1] Sucipto, AdiWidodo. PolitikPerempuanBukanGerhana, Esai-EsaiPilihan. Jakarta: Kompas, 2005.

[2] Mujani, Syaiful Religious Democrat Democratic Culture and Muslim Political Participation in Post Soeharto Indonesia. Disertasi, The Ohio State University, 2003.
[3] Lussier, Danielle. Political participation and The Fate of Regime Change in Rusia and Indonesia. DisertasiUniversitas California Berkeley. 2011.

[4] Rustanto,BambangPerempuandalamPemerintahanLokal:Da mpakPerubahanStrukturPemerintahanLokalTerhadapPosisi PerempuandalamMasyarakat di Kerala India danNagariKamangHilir Sumatera Barat. DisertasiUniversitas Indonesia. 2008.

[5] Fatmariza.KembalikeNagaridanReposisiPerempuan Minangkabau dalamInstitusiNagari, DisertasiUniversitas Indonesia 2012

[6] Hasibuan, Muhammad Umar Syadat. GerakanPolitikMahasiswa:StudiKasusPolarisasiGerakanMa hasiswaPada Masa Pemerintahan BJ Habiebiedan Abdurrahman Wahid.DisertasiUniversitas of Indonesia. (2010)

[7] Aspinall, Edward. Student Dissent in Indonesia in 1980s, Working paper 79 The Centre of Southeast Asian Studies Monash University. 1993.

[8] Jackson, Elisabeth. 'Warring Words': Students and The State in New Order Indonesia,1966-1998. 2005.

[9] Evans, Heather Kathleen. The Young American Voter: The Political Participation of College and Non-College Youth. |Dissertation, 2009.

[10] Putnam, Robert David. Making Democracy Work, Civic Tradition in Modern Italy.Princeton, New Jersey. Princeton University Press. 1993.

[11] Mc.Farland, Adam Daniel., Thomas, Reuben Jack. Bowling Young, How Youth Voluntary Association Influence Adult Political Participation. American Sociological Review, 71 (3): 401-425, 2006.

[12] Burn, Nancy., Schlozman, Lehman Kay., Verba, Sidney. The Private Root of Public Action, Gender, Equality and Political Participation. Cambridge: Harvard University Press. 2001.

[13] Persson, Mikael. Does Type of Education Affect Political Participation? Result from a Panel Survey of Swedish Adolescents. Journal of Scandinavian Political Studies. 35 (3): 198-221. 2012.

[14] Taylor, Jami.K, Clerkin, Richard.M. Public Service Motivation and Political Action in College Undergraduate. Journal Politics and Policy, 39 (5): 715-740. 2011.

[15] Swank, E.W. Predictors of Political Activism among Social Work Student. Journal of Social Work Education, 48 (2): 245-265, 2012.

[16] Stout, Michael Daniel. Social Capital and Inequality in Political Participation.Disertasi, The Pennsylvania State University. 2008. 
[17] Aspinall, Edward. Opposing Soeharto: Compromise, Resistance, and Regime Change in Indonesia, Stanford, Calif. : Stanford University Press,2005.

[18] Huntington, Samual Philips. No Easy Choice: Political Participation in Developing Countries. England: Harvard University Press. 1976.

[19] Altbach, Philip G. Student Politics in The Third World. Higher Education, 13, 635-655. 1984.

[20] Simmon, Jack.Russel., Lily, B. The University and StudentPoliticalEngagement

[21] http://journals.cambridge.org.ezproxy.auckland.ac.nz/down load.php? , 2010.

[22] Verba, Sidney., Schlozman,Kay Lehman., Burns, Nancy. Family Ties Understanding the Intergenerational Transmission of Participation.” Dalam Zuckerman, Alan S. ed. The Social Logic of Politics, Philadelphia: Temple University Press, 2005.

[23] Inglehart, Ronald., Norris, Pippa. Rising Tide: Gender Equality and Cultural Change around The World. New York. Cambridge University, Press2003.

[24] Inglehart, Ronald., Norris, Pippa. The Developmental Theory of the Gender Gap: Women's and Men's Voting Behavior in Global Perspective, International Political Science Review 21 (4), 441-463, 2000. 